\title{
EFEKTIVITAS PENGAWETAN BAMBU PETUNG DAN GEWANG MENGGUNAKAN BORON DAN CCB SECARA RENDAMAN DINGIN DAN BOUCHERIE YANG DIMODIFIKASI
}

\section{(The Effectivity of Preservative Treatment in Petung Bamboo dan Gewang Using Boron and CCB by Cold Soaking and Modified Boucherie Methods)}

\author{
Made Widiadnyana Wardiha, Rudi Setiadji Agustiningtyas, \\ \& I Wayan Avend Mahawan Sumawa
}

\author{
Balai Penelitian dan Pengembangan Perumahan Wilayah II Denpasar \\ Werdhapura Village Center, J1. Danau Tamblingan No. 49, Sanur, Denpasar 80228, \\ Telp. (0361) 287791, 288526 \\ E-mail : made.wardiha@rocketmail.com
}

Diterima 12 Februari 2018, direvisi 2 April 2018, disetujui 4 Juni 2018

\begin{abstract}
Bamboo and gewang midrib are two materials developed as wood substitute in the shape form of lamina products. However, the disadvantage of bamboo and gewang is susceptible to destroying organisms. This paper analyzes the effectiveness of petung bamboo and gewang midrib treatment to improve its durability against destroying organisms. This research investigated the durability of petung bamboo and gewang midrib againts subterranean termites, dry wood termites, wood rotting fungi and dry wood post powder beetles. Treatments were conducted by applying boron and CCB (copper-chrome-boron) using cold immersion and modified Boucherie methods. Durability was tested according to Indonesian Standard SNI 01-7207-2006, while retention and penetration were calculated based on weight, volume, and solution concentrations. The results showed that boron was effective to improve the durability of petung bamboo againts subterranean termites, dry wood termites, and wood rotting fungi, while its resistance againts dry wood post powder beetles, boron and CCB were equally effective. Boron was more effective to improve durability to wood rotting fungi and dry wood post powder beetles in gewang midrib, while both preservatives were similarly effective against subterranean termites and dry wood termites. It is noticably that CCB treatment changed the wood natural color. Modified Boucherie method provides high retention but low penetration level compare to immersion method.
\end{abstract}

Keywords: Boron, CCB, immersion, modified Boucherie, preservation

\begin{abstract}
ABSTRAK
Bambu dan pelepah gewang merupakan dua jenis bahan yang mulai dikembangkan sebagai pengganti kayu dalam bentuk produk lamina. Namun, salah satu kelemahan dari bambu dan gewang adalah mudah terserang organisme perusak. Tulisan ini menganalisis efektivitas pengawetan bambu petung dan pelepah gewang untuk meningkatkan ketahanannya terhadap organisme perusak. Tujuan penelitian adalah untuk mengetahui peningkatan keawetan melalui pengujian ketahanan terhadap rayap tanah, rayap kayu kering, jamur pelapuk, dan kumbang bubuk kayu kering, serta mengetahui indikator keterawetannya melalui perhitungan dan pengamatan retensi dan penetrasi. Bahan pengawet yang digunakan adalah boron dan CCB (copper-chrome-boron) dengan metode rendaman dingin dan Boucherie yang dimodifikasi. Pengujian keawetan mengacu pada SNI 01-7207-2006, sementara pengujian retensi dan penetrasi menggunakan rumus perbandingan berat dan volume contoh serta konsentrasi pengawet. Hasil pengujian menunjukkan bahwa boron efektif pada bambu petung untuk meningkatkan ketahanan terhadap rayap tanah, rayap kayu kering, serta jamur pelapuk, sedangkan untuk ketahanan terhadap kumbang bubuk kayu kering, efektivitas boron dan CCB hampir setara.
\end{abstract}


Untuk pelepah gewang, boron lebih efektif meningkatkan ketahanan terhadap jamur pelapuk dan kumbang bubuk kayu kering, sedangkan untuk rayap tanah dan rayap kayu kering, kedua bahan pengawet memiliki efektivitas setara. Dalam penggunaan CCB yang perlu diperhatikan adalah adanya perubahan warna alami yang terjadi setelah pengawetan. Pengawetan dengan metode Boucherie yang dimodifikasi menghasilkan retensi yang tinggi, namun penetrasi lebih rendah jika dibandingkan dengan metode perendaman.

Kata kunci: Boron, CCB, modifikasi Boucherie, pengawetan, perendaman

\section{PENDAHULUAN}

Bambu dan pelepah gewang merupakan dua jenis bahan terbarukan yang mulai dikembangkan menjadi bahan baku pengganti kayu dalam bentuk produk bambu lamina dan panel gewang laminasi (Muliawan, 2014; Budiana \& Pranata, 2013; Sulastiningsih \& Santoso, 2012). Salah satu kelemahan bahan tersebut adalah keawetannya rendah, sehingga rentan terserang organisme perusak (Aini, Morisco, \& Anita, 2009). Ketahanan bambu petung (Dendrocalamus asper Bakcer ex K. Heyne) termasuk kelas IV atau tidak tahan terhadap rayap tanah (Jasni, Damayanti, \& Pari, 2017). Salah satu cara untuk meningkatkan keawetan alami adalah dengan melakukan pengawetan menggunakan bahan pengawet yang bersifat racun terhadap organisme perusak seperti rayap, jamur, atau kumbang bubuk (Abdurrohim, 1996; Krisdianto, Sudika, Wahyudi, \& Muslich, 2015).

Bahan pengawet yang diizinkan untuk digunakan di antaranya boron dan CCB (copperchrome-boron). Boron merupakan campuran boraks dengan asam borat. Boraks $\left(\mathrm{Na}_{2} \mathrm{~B}_{4} \mathrm{O}_{7}\right)$ dan asam borat $\left(\mathrm{H}_{3} \mathrm{BO}_{3}\right)$ dipilih sebagai bahan pengawet kayu karena toksisitas rendah (Yamauchi, Sakai, Watanabe, Kubo, \& Matsue, 2007). CCB atau dalam bahasa Indonesia adalah Tembaga-Khromium-Boron, merupakan campuran antara tembaga sulfat $\left(\mathrm{CuSO}_{4} \cdot 5 \mathrm{H}_{2} \mathrm{O}\right)$, natrium dichromat $\left(\mathrm{Na}_{2} \mathrm{Cr}_{2} \mathrm{O}_{7}-2 \mathrm{H}_{2} \mathrm{O}\right)$, serta asam borat $\left(\mathrm{H}_{3} \mathrm{BO}_{3}\right)$ dengan perbandingan komposisi masing-masing 35\%: 40\%: 25\% (Barly, Lelana, \& Ismanto, 2010). Metode pengawetan yang dapat digunakan diantaranya rendaman dingin (Suhaendah \& Siarudin, 2014) dan metode Boucherie yang dimodifikasi (Muslich \& Rulliaty, 2014). Modifikasi metode Boucherie dapat dilakukan dengan memanfaatkan kapilaritas bambu atau dengan proses vakum tekan.
Keefektifan metode pengawetan dapat diketahui dari tingkat keawetan dan keterawetan dari bahan yang diawetkan seperti nilai retensi, penetrasi, dan keawetan terhadap organisme perusak. Untuk mengetahui hal tersebut maka dilakukan pengujian terhadap bambu dan pelepah gewang yang telah diawetkan. Tujuan penelitian ini adalah untuk melihat tingkat keawetan dan keterawetan bambu dan pelepah gewang sebelum dan setelah pengawetan dengan variasi bahan pengawet boron dan CCB dengan metode rendaman dan Bouncherie yang dimodifikasi. Kebaruandaripenelitianiniadalahkajianmengenai keawetan dan keterawetan pelepah gewang yang belum banyak dilakukan sebelumnya serta analisis yang dilakukan untuk melihat bahan dan metode pengawetan yang tepat digunakan dalam kaitannya dengan pembuatan produk pengganti kayu berbahan bambu dan gewang untuk interior ataupun ekterior bangunan. Hasil penelitian ini dapat dijadikan dasar dalam pengembangan produk pengganti kayu selanjutnya.

\section{BAHAN DAN METODE}

\section{A. Lokasi dan Waktu Penelitian}

Penelitian dilakukan di dua tempat yaitu di laboratorium bahan bangunan Balai Litbang Perumahan Wilayah II Denpasar untuk penyiapan dan perlakuan terhadap contoh uji, serta di Laboratorium Teknologi Peningkatan Mutu Kayu, Departemen Hasil Hutan, Fakultas Kehutanan Institut Pertanian Bogor untuk pengujian keawetan dan keterawetan.

\section{B. Bahan dan Metode}

Bahan baku yang digunakan yaitu bambu petung dengan ketebalan $>10 \mathrm{~mm}$ serta pelepah gewang dengan ukuran penampang 5-11 cm dan panjang antara 2,5-3 meter. 
Bahan baku disiapkan untuk pengujian dengan pengulangan sebanyak tiga kali. Bambu petung diperoleh dari Kabupaten Tabanan, Provinsi Bali, sedangkan pelepah gewang diperoleh dari Kabupaten Kupang, Provinsi Nusa Tenggara Timur.

Untuk pengawetan dengan metode perendaman dingin, bahan dan alat yang digunakan yaitu: wadah berupa tong untuk perendaman dengan dimensi tinggi 90 $\mathrm{cm}$ dan diameter $80 \mathrm{~cm}$ dan bilah bambu petung dengan panjang $90 \mathrm{~cm}$, lebar $5 \mathrm{~cm}$, dan tebal $1 \mathrm{~cm}$. Pelepah gewang dibelah dua bagian dan dipipihkan dengan panjang $90 \mathrm{~cm}$, lebar pangkal rata-rata $8 \mathrm{~cm}$, lebar ujung rata-rata $4 \mathrm{~cm}$, dan ketebalan rata-rata $1 \mathrm{~cm}$. Untuk pengawetan dengan metode Boucherie yang dimodifikasi, bahan dan alat yang digunakan adalah alat Boucherie yang dimodifikasi menggunakan prinsip tekanan untuk memasukkan bahan pengawet ke dalam material seperti terlihat pada Gambar 1, serta bambu berbentuk buluh dengan diameter 14 $\mathrm{cm}$, panjang 2 meter, dan ketebalan rata-rata $1,5 \mathrm{~cm}$.

Bahan pengawet yang digunakan adalah boron 3\% (campuran boraks dan asam borat) dan CCB. Bahan pengawet tersebut sebelum digunakan diencerkan terlebih dahulu dengan menambahkan air hingga konsentrasi 5\%.

Pengawetan dengan metode perendaman dingin dilakukan pada tong perendaman. Sampel pengujian dimasukkan ke dalam tong dan direndam bahan pengawet setinggi \pm 10 cm dari tumpukan sampel teratas selama kurang lebih tiga hari. Pemberat diletakkan di bagian atas sampel agar bahan bisa terendam dengan baik. Bambu dan pelepah gewang diawetkan dengan dua variasi bahan pengawet yaitu boron dan CCB. Setelah tiga hari, sampel bambu dan gewang diangkat dan ditimbang untuk pengukuran retensi. Setelah itu bahan dikeringudarakan untuk mencapai kadar air 12\% untuk dilakukan pengujian penetrasi dan keawetan. Pengukuran kadar air dilakukan dengan alat ukur kadar air digital.

Pengawetan dengan metode Boucherie yang dimodifikasi dilakukan dengan tangki bertekanan dimana bahan pengawet dimasukkan ke dalam tabung yang diberi tekanan menggunakan kompresor. Bambu yang diawetkan dipasang pada nozzle dan pengawetan dilakukan dalam tekanan sebesar 2 bar (0,2 $\mathrm{MPa}$ atau setara $2 \mathrm{~kg} /$ $\mathrm{cm}^{2}$ ). Pemberian tekanan dilakukan sampai bahan pengawet menembus bambu dan kemudian tekanan diteruskan hingga 30 menit setelahnya.

Data yang dikumpulkan berupa berat awal, berat akhir, dimensi sampel yang diuji, serta konsentrasi bahan pengawet dan lama waktu pengawetan. Setelah pengawetan dilakukan, bahan bambu dan gewang diuji tingkat keawetan dan keterawetannya di laboratorium. Tingkat keawetan dilihat dari kehilangan berat pada saat diumpankan kepada organisme perusak yaitu rayap tanah, rayap kayu kering, jamur pelapuk dan kumbang bubuk. Pengujian keawetan dilakukan di laboratorium pengeringan dan pengawetan kayu, bagian teknologi peningkatan mutu kayu,

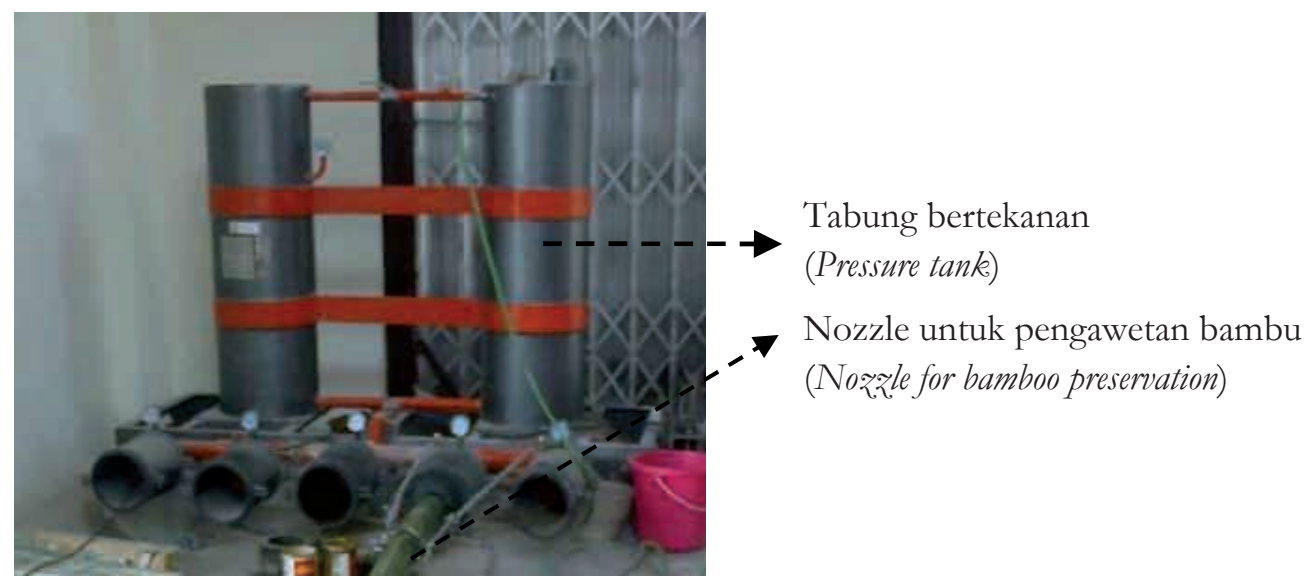

Gambar 1. Alat Boucherie yang sudah dimodifikasi

Figure 1. Modified Boucherie instrument 
Departemen Hasil Hutan, Fakultas Kehutanan, Institut Pertanian Bogor berdasarkan SNI 017207-2006 tentang uji ketahanan kayu dan produk kayu terhadap organisme perusak kayu. Pengujian keawetan dilakukan dengan terlebih dahulu menyiapkan sampel dari bahan bambu dan pelepah gewang dengan ukuran $5 \mathrm{~cm}$ x 5 $\mathrm{cm} \times 35 \mathrm{~cm}$ dengan pengulangan sebanyak tiga kali.

Tingkat keterawetan dilihat dari nilai retensi dan penetrasi. Nilai retensi, dihitung menggunakan rumus:

$$
R=\frac{B_{1}-B_{0}}{V} \times K
$$

Sumber: Hakim, Hartono, dan Zalukhu (2012)

Keterangan (Remarks) :

$\mathrm{R}=$ Retensi bahan pengawet $\left(\mathrm{kg} / \mathrm{m}^{3}\right) ; B_{1}=$ Berat contoh uji setelah pengawetan $(\mathrm{kg}) ; B_{0}=$ Berat contoh uji sebelum pengawetan $(\mathrm{kg}) ; V=$ Volume contoh uji $\left(\mathrm{m}^{3}\right)$; $K=$ Konsentrasi larutan bahan pengawet yang digunakan $(\%)$

Nilai penetrasi dihitung dengan mengukur kedalaman penembusan bahan pengawet ke dalam bahan yang diawetkan. Metode ini dilakukan pada semua bahan uji untuk dua macam bahan pengawet, dan metode pengawetan.

\section{Analisis Data}

Data yang diperoleh dan diolah kemudian dibandingkan satu sama lain, serta dilakukan perbandingan dengan hasil penelitian serupa yang sudah pernah dilakukan. Analisis juga dilihat berdasarkan tabel peningkatan keawetan bahan sebelum dan sesudah diawetkan. Tingkat kepercayaan terhadap data dan grafik dapat dilihat dari standar deviasi dari masing-masing data. Untuk mengetahui efektivitas metode pengawetan dan bahan pengawet yang digunakan, dilakukan perbandingan antara kedua metode dan kedua jenis bahan pengawet dengan melihat nilai retensi, kehilangan berat untuk empat jenis organisme perusak, serta aspek lain seperti perubahan warna dan limbah pengawet. Berdasarkan analisis tersebut, dapat disimpulkan efektivitas bahan pengawet dan metode pengawetan yang telah dilakukan.

\section{HASIL DAN PEMBAHASAN}

\section{A. Keawetan dan Keterawetan Bambu Petung dan Pelepah Gewang}

Berdasarkan hasil pengukuran dan analisis yang dilakukan, diperoleh data retensi untuk buluh bambu petung, bilah bambu petung, dan pelepah gewang seperti terlihat pada Tabel 1.

Dari data pada Tabel 1 dapat dianalisis beberapa hal yaitu, retensi buluh bambu petung dengan metode Boucherie yang dimodifikasi lebih rendah daripada retensi bambu petung dengan metode perendaman dingin. Metode Boucherie yang dimodifikasi seharusnya lebih efektif karena memanfaatkan pembuluh kapiler bambu dalam arah longitudinal (Muslich \& Rulliaty, 2014; Susanti, 2001). Menurut Muslich dan Rulliaty (2014), nilai retensi pada bambu petung dengan bahan pengawet CCB dan metode Boucherie adalah $13,62 \mathrm{~kg} / \mathrm{m}^{3}$ untuk bagian pangkal dan $9,12 \mathrm{~kg} / \mathrm{m}^{3}$ untuk bagian ujung. Nilai retensi dari hasil penelitian ini cukup jauh dari penelitian

Tabel 1. Nilai retensi $\left(\mathrm{kg} / \mathrm{m}^{3}\right)$ bambu dan pelepah gewang yang diawetkan dengan pengawet boron dan CCB menggunakan metode rendaman dan Boucherie yang dimodifikasi

Table 1. Retention values $\left(\mathrm{kg} / \mathrm{m}^{3}\right)$ of bamboo and gewang midrib treated with boron and CCB using immersion and modified Boucherie method

\begin{tabular}{|c|c|c|c|c|c|c|}
\hline \multirow[b]{2}{*}{$\begin{array}{l}\text { Metode pengawetan } \\
\text { (Preservation methods) }\end{array}$} & \multicolumn{2}{|c|}{$\begin{array}{l}\text { Buluh bambu petung } \\
\text { (Reeds of petung bamboo) }\end{array}$} & \multicolumn{2}{|c|}{$\begin{array}{l}\text { Bilah bambu petung } \\
\text { (Blades of petung bamboo) }\end{array}$} & \multicolumn{2}{|c|}{$\begin{array}{l}\text { Pelepah gewang } \\
\text { (Gewang midrib) }\end{array}$} \\
\hline & $\begin{array}{l}\text { Boron } \\
\text { (Boron) }\end{array}$ & $\begin{array}{c}\text { CCB } \\
\text { (Copper-chrome- } \\
\text { boron) }\end{array}$ & Boron (Boron) & $\begin{array}{c}\text { CCB } \\
\text { (Copper-chrome- } \\
\text { boron) }\end{array}$ & $\begin{array}{l}\text { Boron } \\
\text { (Boron) }\end{array}$ & $\begin{array}{c}\text { CCB } \\
\text { (Copper-chrome- } \\
\text { boron) }\end{array}$ \\
\hline Rendaman (Immersion) & & & 11,26 & 8,67 & 8,73 & 7,56 \\
\hline $\begin{array}{l}\text { Boucherie modifikasi } \\
\text { (Modified Boucherie) }\end{array}$ & 3,75 & 4,81 & & & & \\
\hline
\end{tabular}


sebelumnya. Ada beberapa hal yang kemungkinan menjadi penyebab rendahnya nilai retensi:

1. Proses penebangan dan pengawetan dilakukan pada musim kemarau. Menurut Irawaty (2000), hasil terbaik dari metode Boucherie bisa dicapai selama musim hujan atau setelah musim hujan dan kegagalan bisa terjadi selama musim kemarau;

2. Bambu yang ditebang merupakan bambu yang cukup dewasa dengan usia sekitar 5 tahun karena syarat untuk digunakan sebagai bahan bambu laminasi adalah bambu tersebut harus cukup tua. Namun, dalam hal pengawetan dengan Boucherie, akan lebih efektif apabila dilakukan pada bambu muda atau segar dengan kadar air yang tinggi (Damayanti, Agustiningtyas, \& Kuswara, 2017).

Standar SNI 03-5010.1-1999 menyatakan bahwa syarat retensi untuk penggunaan di bawah atap adalah $8 \mathrm{~kg} / \mathrm{m}^{3}$ dan penggunaan di luar atap adalah $11 \mathrm{~kg} / \mathrm{m}^{3}$ (Priadi \& Pratiwi, 2014), maka dari hasil di atas, bahan yang bisa digunakan untuk di luar atap adalah bilah bambu petung yang diawetkan dengan boron menggunakan metode perendaman. Untuk penggunaan di bawah atap yaitu bilah bambu petung yang diawetkan menggunakan CCB dengan metode perendaman serta pelepah gewang yang diawetkan dengan perendaman menggunakan boron ataupun CCB.
Nilai retensi bahan pengawet yang masuk ke bahan pelepah gewang lebih rendah daripada bahan bambu petung. Hal ini kemungkinan disebabkan karena perbedaan kandungan lignin serta kepadatan bambu dan pelepah gewang. Kandungan lignin pada serat bambu berkisar antara 25-30\% (Fatriasari \& Hermiati, 2008), sedangkan kandungan lignin pada serat pelepah gewang yaitu 14,97\% (Achmad, 2016), dimana kandungan lignin cenderung mengikat bahan pengawet seperti unsur tembaga dan krom (Febrianto, Gumilang, Carolina, \& Yoresta, 2014). Perbedaan ini kemungkinan dipengaruhi oleh kepadatan gewang yang kisarannya $0,5 \mathrm{~g} /$ $\mathrm{cm}^{3}$ (Budiana \& Pranata, 2013), sedangkan kepadatan bambu petung kisarannya $0,86 \mathrm{~g} / \mathrm{cm}^{3}$ (Haris, 2008). Kepadatan bambu petung yang lebih tinggi menyebabkan jumlah sel serat lebih banyak dengan kemungkinan jumlah lignin yang mengikat bahan pengawet juga lebih banyak.

Retensi bahan pengawet CCB pada bilah bambu petung dengan metode perendaman yaitu sekitar $8,67 \mathrm{~kg} / \mathrm{m}^{3}$, tidak jauh berbeda dengan hasil penelitian sebelumnya yang menggunakan metode Boucherie yang berkisar antara 9,12$13,62 \mathrm{~kg} / \mathrm{m}^{3}$ dari ujung sampai ke pangkal bambu (Muslich \& Rulliaty, 2014). Dalam hal ini berarti pengawetan dengan metode perendaman cukup efektif jika dilihat dari nilai retensinya.

Tabel 2. Penetrasi boron dan CCB pada bambu petung dan pelepah gewang menggunakan metode pengawetan rendaman dan Boucherie yang dimodifikasi

Table 2. Boron and CCB penetration of bamboo petung and gewang midrib by immersion and modified Boucherie preservation methods

\begin{tabular}{|c|c|c|c|c|c|c|}
\hline $\begin{array}{c}\text { Penetrasi } \\
\text { (Penetration, } \mathrm{mm} \text { ) }\end{array}$ & $\begin{array}{l}\text { Buluh bambu } \\
\text { petung (Reeds } \\
\text { of petung } \\
\text { bamboo), boron- } \\
\text { boucherie }\end{array}$ & $\begin{array}{l}\text { Buluh bambu } \\
\text { petung (Reeds } \\
\text { of petung } \\
\text { bamboo), CCB- } \\
\text { boucherie }\end{array}$ & $\begin{array}{l}\text { Bilah bambu } \\
\text { petung (Blades } \\
\text { of petung } \\
\text { bamboo), } \\
\text { boron- } \\
\text { rendam (Boron } \\
\text { immersion) } \\
\end{array}$ & $\begin{array}{l}\text { Bilah bambu } \\
\text { petung (Blades } \\
\text { of petung } \\
\text { bamboo), CCB- } \\
\text { rendam (Boron } \\
\text { immersion) }\end{array}$ & $\begin{array}{c}\text { Pelepah } \\
\text { gewang } \\
\text { (Gewang } \\
\text { midrib), boron- } \\
\text { rendam (Boron } \\
\text { immersion) }\end{array}$ & $\begin{array}{c}\text { Pelepah } \\
\text { gewang } \\
\text { (Gewang } \\
\text { midrib), CCB- } \\
\text { rendam (Boron } \\
\text { immersion) }\end{array}$ \\
\hline $\begin{array}{l}\text { Ulangan } \\
\text { (Repetition) } 1\end{array}$ & 9,96 & 8,59 & 3,86 & 3,73 & 5,44 & 4,99 \\
\hline $\begin{array}{l}\text { Ulangan } \\
\text { (Repetition) } 2\end{array}$ & 10 & 9,09 & 3,8 & 3,93 & 6,19 & 5,45 \\
\hline $\begin{array}{l}\text { Ulangan } \\
\text { (Repetition) } 3\end{array}$ & 9,93 & 9,46 & 3,85 & 3,65 & 5,88 & 4,82 \\
\hline $\begin{array}{l}\text { Rata-rata } \\
(\text { Average })\end{array}$ & 9,96 & 9,05 & 3,84 & 3,77 & 5,84 & 5,09 \\
\hline $\begin{array}{l}\text { Stdev (Standard } \\
\text { deviation) }\end{array}$ & 0,04 & 0,44 & 0,03 & 0,14 & 0,38 & 0,33 \\
\hline
\end{tabular}


Selain nilai retensi, nilai penetrasi dapat juga menjadi pertimbangan untuk melihat efektivitas pengawetan yang dilakukan. Berdasarkan data penetrasi pada Tabel 2 dapat dianalisis bahwa nilai penetrasi yang baik berdasarkan SNI 017205-2006 tentang uji bahan pengawet kayu pada kayu dan produk kayu adalah minimal $10 \mathrm{~mm}$. Berdasarkan ketentuan tersebut, hanya satu bahan uji yang memenuhi persyaratan tetapi secara keseluruhan dapat disimpulkan bahwa penetrasi pada buluh bambu petung dengan menggunakan metode Boucherie yang dimodifikasi memiliki nilai penetrasi paling baik.

Berdasarkan kelas keterawetan kayu yang telah ditetapkan oleh Barly dan Martawijaya (2000), persentase penetrasi buluh bambu termasuk kelas keterawetan I atau mudah (permeable), sedangkan bilah bambu termasuk kelas III atau sukar (resistant), dan pelepah gewang termasuk kelas II atau sedang (moderately resistant).

Pengawetan dengan menggunakan boron, baik dengan metode Boucherie yang dimodifikasi maupun dengan perendaman dingin, sama-sama menghasilkan nilai penetrasi yang lebih tinggi dibandingkan CCB. Hal ini menunjukkan bahwa bahan pengawet boron lebih mudah masuk ke dalam bahan bambu petung dan gewang dibandingkan dengan CCB.

Selain keterawetan yang dilihat dari nilai retensi dan penetrasi, keefektivitasan pengawetan paling utama dilihat dari ketahanannya terhadap serangan organisme perusak. Ketahanan terhadap organisme perusak dapat dilihat dari nilai kehilangan berat dari bahan yang diumpankan kepada organisme perusak tersebut yang dapat digolongkan ke dalam klasifikasi ketahanan berdasarkan SNI 01.7202-2006. Data hasil pengujian keawetan bambu dan gewang terdapat pada Tabel 3.

Berdasarkan Tabel 3, perlakuan pengawetan menggunakan boron maupun CCB sangat signifikan berpengaruh terhadap ketahanan bambu petung dan pelepah gewang baik dalam bentuk bilah maupun buluh, baik dengan cara direndam maupun diawetkan dengan metode Boucherie yang dimodifikasi. Hal ini dapat dilihat dari kenaikan yang signifikan dari tingkat keawetan bahan yang diuji, yaitu dari kelas IV (tidak tahan) untuk rayap tanah, rayap kayu kering, dan kumbang bubuk, serta kelas III (agak tahan) untuk jamur pelapuk, menjadi kelas I (sangat tahan) untuk rayap tanah dan kelas II (tahan) untuk rayap kayu kering, jamur pelapuk, dan kumbang bubuk.

Jika dilihat dari nilai retensi, retensi pengawetan dengan metode Boucherie yang dimodifikasi lebih rendah daripada metode rendaman, tetapi menghasilkan tingkat keawetan yang hampir sama. Hal ini kemungkinan karena jumlah bahan pengawet yang masuk pada seluruh sampel uji sudah melampaui batas minimum yang dibutuhkan untuk meningkatkan keawetan.

Berdasarkan Tabel 3, jika hanya dibandingkan persentase kehilangan berat berdasarkan variasi material (bahan pengawet) dan metode pengawetan, efektivitas metode Boucherie dan perendaman tidak jauh berbeda untuk ketahanan terhadap rayap tanah serta kumbang bubuk kayu kering. Metode Boucherie lebih efektif pada pengawetan bambu dengan bahan pengawet boron untuk meningkatkan ketahanan terhadap rayap kayu kering, sedangkan metode perendaman lebih efektif untuk meningkatkan ketahanan terhadap jamur pelapuk baik menggunakan bahan pengawet boron ataupun CCB.

Selanjutnya, perbandingan efektivitas pengawet boron dan CCB untuk bilah bambu petung, metode pengawetan perendaman lebih efektif menggunakan pengawet boron untuk meningkatkan ketahanan terhadap rayap tanah dan jamur pelapuk. Bahan pengawet boron juga efektif untuk menahan serangan rayap kayu kering pada buluh bambu dengan metode Boucherie yang dimodifikasi, sementara untuk bahan pelepah gewang, boron lebih efektif untuk menahan serangan jamur pelapuk dan kumbang bubuk kayu kering.

\section{B. Efektivitas Pengawetan antara Boron dan CCB}

Selain tingkat keawetan, yang perlu diperhatikan dalam memilih bahan pengawet boron atau CCB adalah perubahan warna yang terjadi pada bahan serta karakteristik pengawet yang berpengaruh pada tingkat terserapnya pengawet ke dalam bahan. 


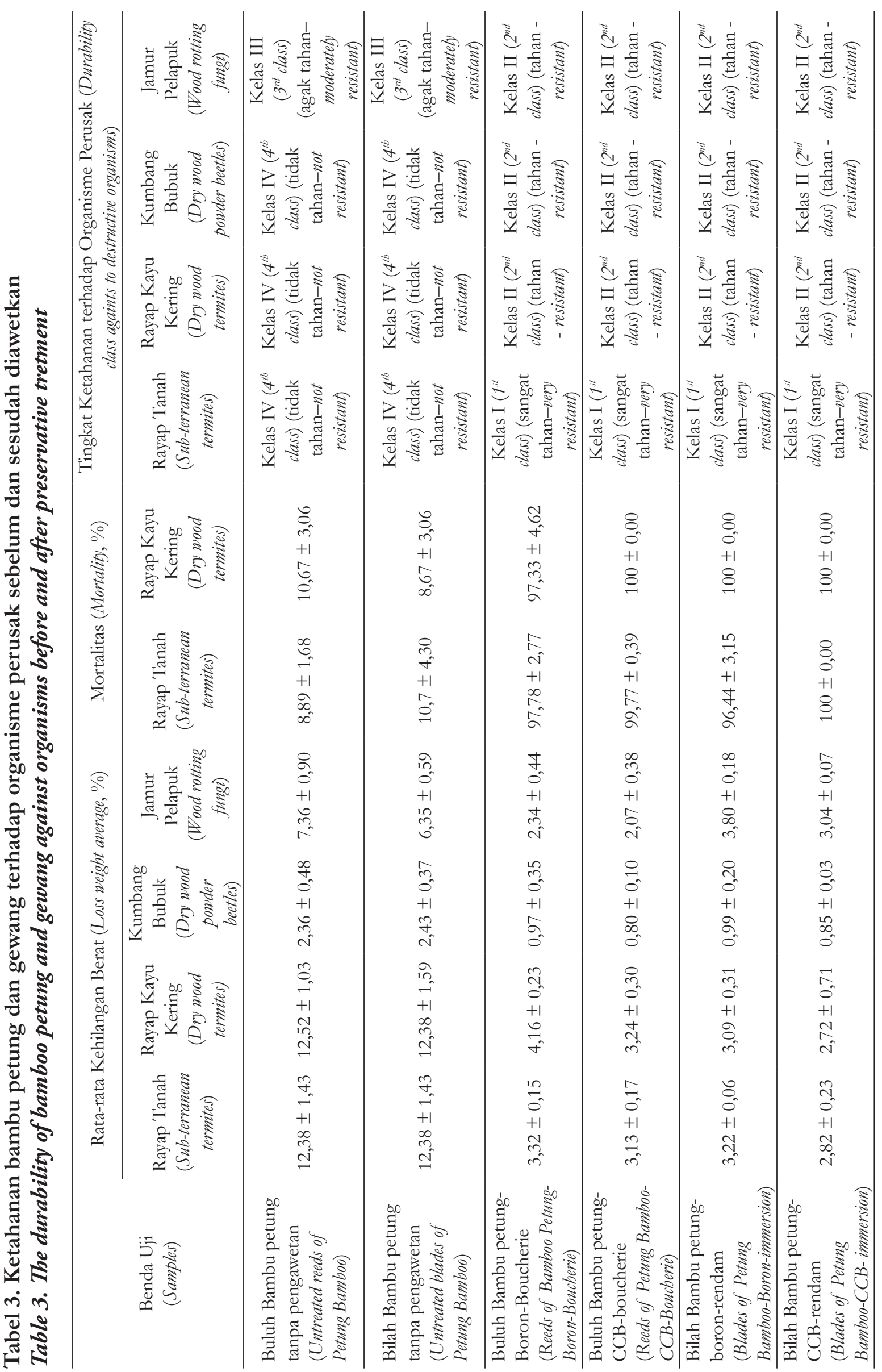




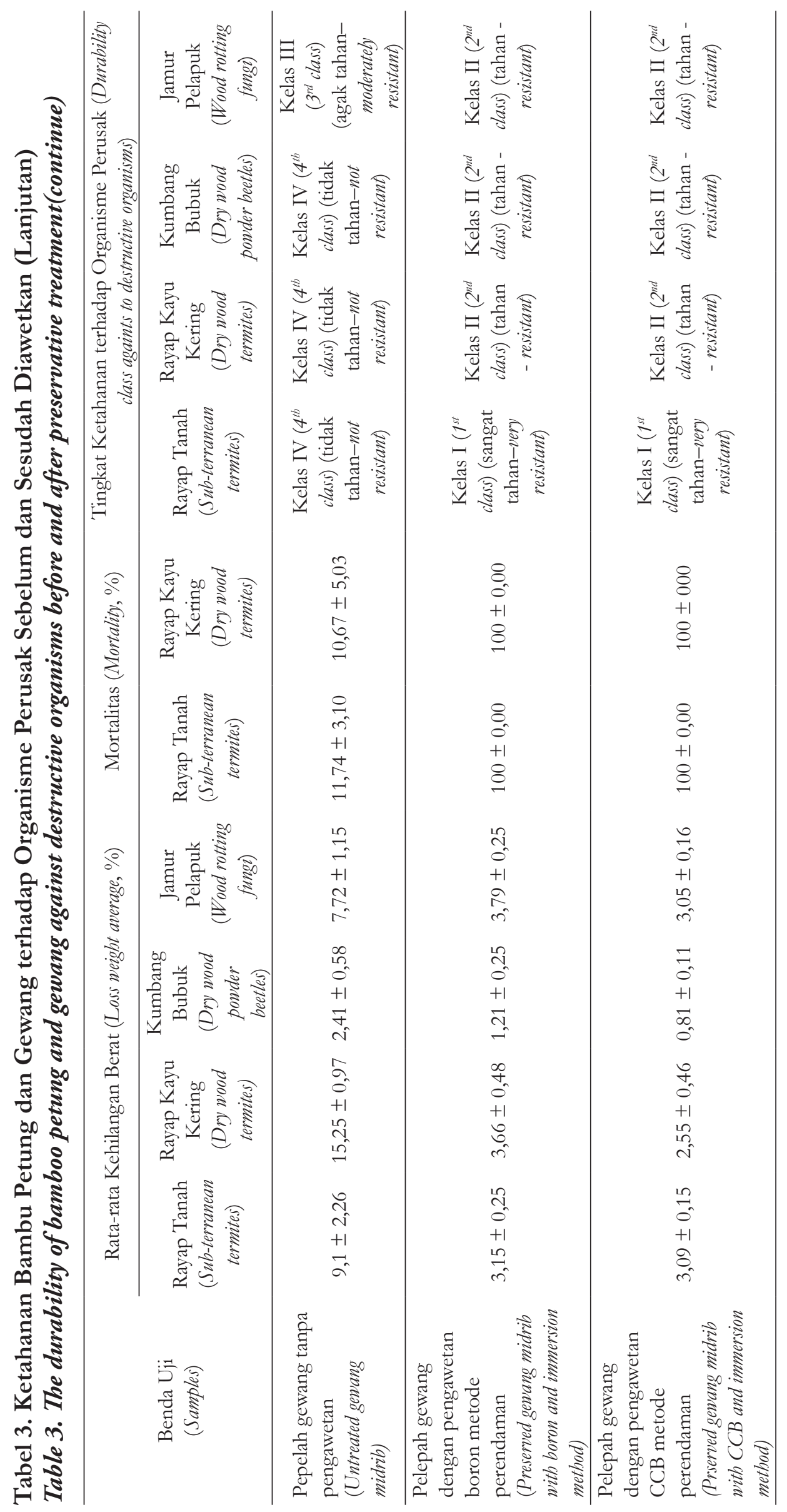


Dari segi perubahan warna, Gambar 2 memperlihatkan foto warna bambu dan gewang sebelum dan sesudah diawetkan dengan boron, sedangkan Gambar 3 memperlihatkan warna bambu dan pelepah gewang sebelum dan sesudah diawetkan dengan CCB. Dari Gambar 2 terlihat bahwa bambu dan pelepah gewang yang diawetkan dengan boron tidak ada perubahan dari warna aslinya, sedangkan pada Gambar 3 terlihat perubahan warna setelah diawetkan dengan CCB dimana bambu dan pelepah gewang berubah menjadi hijau kekuningan. Warna kekuningan tersebut diakibatkan oleh adanya unsur tembaga pada pengawet CCB. Berdasarkan kondisi tersebut dapat disimpulkan bahwa apabila akan mengawetkan bahan tapi tidak menginginkan adanya perubahan warna maka lebih baik menggunakan pengawet boron daripada CCB.

Berdasarkan karakteristik bahan pengawet, dilihat dari nilai retensi dan penetrasi bahan pengawet pada Tabel 1 dan Tabel 2, rata-rata nilai retensi dan penetrasi pengawet boron lebih tinggi daripada pengawet CCB yang menandakan pengawet boron lebih mudah terserap ke dalam bahan bambu dan pelepah gewang daripada CCB. Boron yang merupakan campuran boraks dan asam borat bersifat mudah dilarutkan serta percepatan pelarutan dapat dilakukan dengan menaikkan suhu pelarutnya (Sumaryanto, Hadikusumo, \& Lukmandaru, 2013). Selain itu, keberadaan molekul logam dalam larutan CCB menyebabkan tingkat kepekatan CCB lebih tinggi daripada boron. Untuk metode rendam yang menggunakan bahan bambu dan pelepah gewang yang kering atau memiliki kandungan air yang rendah maka larutan dengan tingkat kepekatan atau konsentrasi lebih rendah akan lebih mudah terserap. Hal berbeda terlihat dari Tabel 1 untuk pengawetan dengan metode Boucherie yang dimodifikasi yang menggunakan bambu buluh yang tidak terlalu kering sehingga masih memiliki kandungan air yang cukup tinggi. Jika masih ada kandungan air, maka larutan yang konsentrasinya lebih tinggi akan lebih mudah terserap karena proses masuknya larutan menggunakan prinsip osmosis dimana larutan yang tingkat konsentrasinya lebih tinggi akan menggantikan air di dalam bahan yang tingkat konsentrasinya lebih rendah. Dari penjelasan tersebut, dapat disimpulkan bahwa untuk pengawetan dengan metode Boucherie yang dimodifikasi menggunakan bahan yang masih memiliki kandungan air tinggi lebih efektif menggunakan pengawet $\mathrm{CCB}$ daripada boron. Namun untuk bahan yang sudah kering dan diawetkan menggunakan metode perendaman, pengawet boron akan lebih efektif.

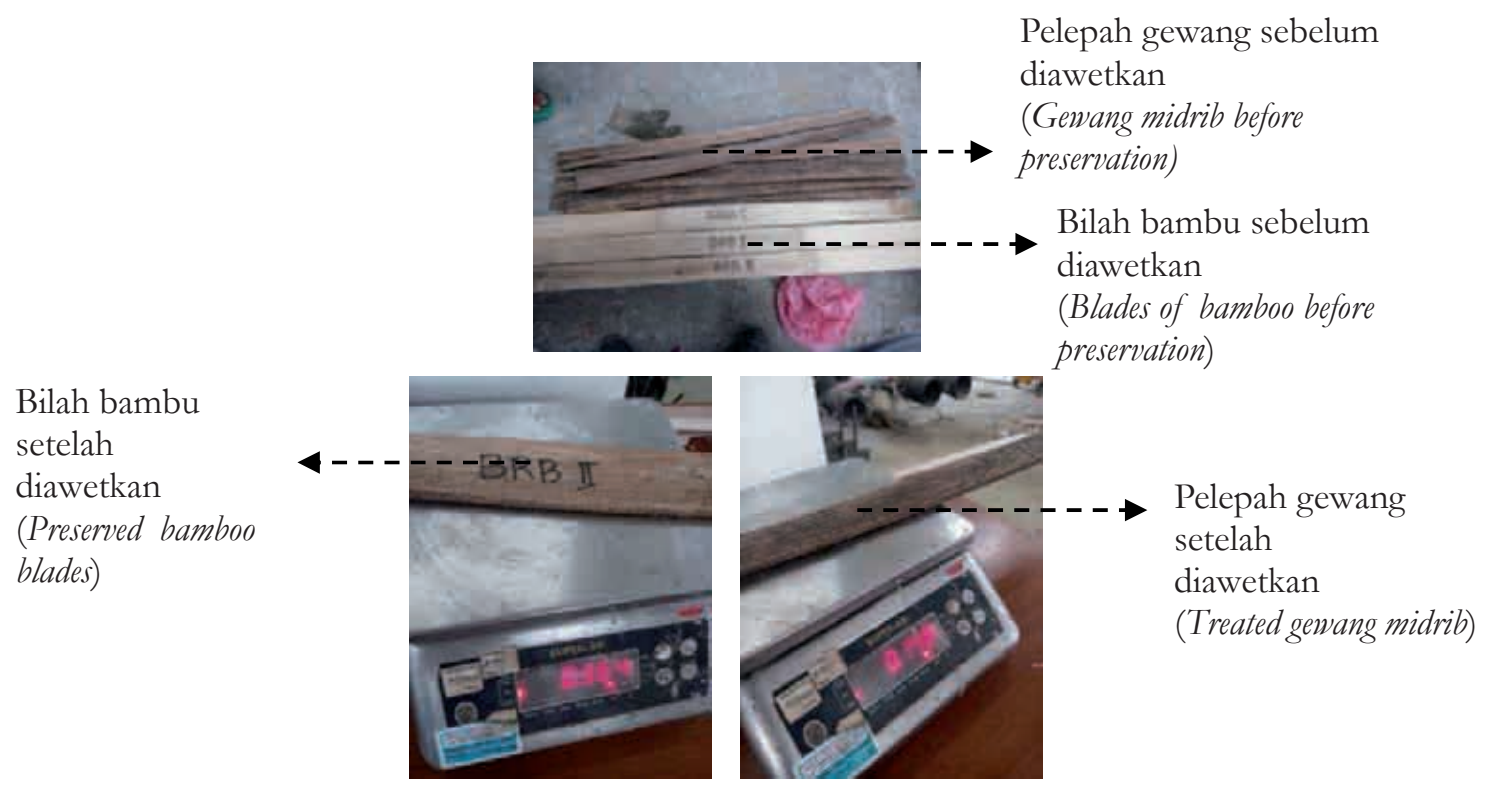

Gambar 2. Perbandingan warna bambu dan pelepah gewang sebelum diawetkan (atas) dan setelah diawetkan (bawah) dengan boron

Figure 2. Comparison of bamboo and gewang midrib colors before preserving (top) and after preserving (bottom) using boron 

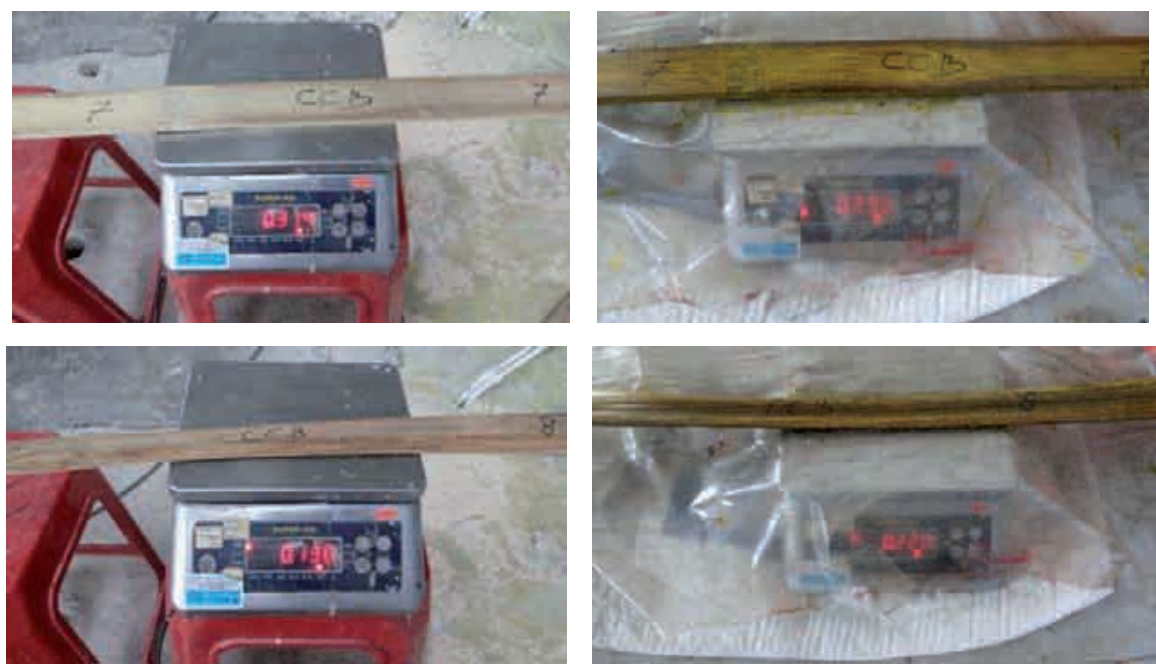

Gambar 3. Perbandingan bambu (atas) dan pelepah gewang (bawah) sebelum diawetkan (kiri) dan setelah diawetkan (kanan) dengan CCB

Figure 3. Comparison of bamboo (top) and gewang midrib (bottom) before preserved (left) and after preserved (right) using $C C B$

\section{KESIMPULAN DAN SARAN}

\section{A. Kesimpulan}

Metode pengawetan Boucherie yang dimodifikasi menghasilkan retensi yang tinggi, namun penetrasi rendah jika dibandingkan dengan metode perendaman. Bahan pengawet boron lebih efektif digunakan pada bambu petung untuk meningkatkan ketahanan terhadap rayap tanah, rayap kayu kering, serta jamur pelapuk. Boron lebih efektif digunakan pada gewang untuk meningkatkan ketahanan terhadap jamur pelapuk dan kumbang bubuk kayu kering. Selain efektif dari segi keawetan dan keterawetan, penggunaan boron juga memiliki kelebihan yang tidak terjadi perubahan warna yang signifikan dari bahan organik yang diuji sebelum dan sesudah diawetkan.

\section{B. Saran}

Dari hasil penelitian ini belum dapat diketahui berapa lama bahan pengawet bertahan dalam sampel yang diuji, baik yang diawetkan dengan pengawet boron dan CCB serta dengan metode Boucherie yang dimodifikasi dan perendaman. Oleh karena itu, perlu dilakukan penelitian terkait jangka waktu ketahanan bahan tersebut baik yang digunakan di dalam maupun di luar ruangan.

\section{UCAPAN TERIMA KASIH}

Ucapan terima kasih disampaikan kepada Balai Litbang Perumahan Wilayah II Denpasar atas data yang digunakan pada makalah ini dan, Prof. Dodi Nandika dari Institut Pertanian Bogor atas masukan dan bantuan pengujian keawetan bahan di Laboratorium Penelitian Hasil Hutan IPB.

\section{DAFTAR PUSTAKA}

Abdurrohim, S. (1996). Pengawetan lima jenis kayu secara pelaburan memakai dua jenis bahan pengawet. Buletin Penelitian Hasil Hutan, 14(5), 204-210.

Achmad, CA. (2016). Sifat fisis dan sifat kimia epidermis pelepah gewang (Corypha utan Lamk.) sertakarakteristik makropartikelnya. (Skripsi). Departemen Hasil Hutan, Fakultas Kehutanan, Institut Pertanian Bogor.

Aini, N., Morisco, \& Anita. (2009). Pengaruh pengawetan terhadap kekuatan dan keawetan produk laminasi bambu. Forum Teknik Sipil, XIX, 979-986.

Barly \& Martawijaya, A. (2000). Keterawetan 95 jenis kayu terhadap impregnasi dengan bahan pengawet CCA. Buletin Penelitian Hasil Hutan, 18(2), 69-78. 
Barly, Lelana, N. E., \& Ismanto, A. (2010). Keefektifan campuran garam TembagaKhromium-Boron terhadap rayap dan jamur perusak kayu. Jurnal Penelitian Hasil Hutan, 28 (3), 222-230.

Budiana, I. G., \& Pranata, Y. A. (2013). Pemodelan metode elemen hingga nonlinier dinding panel gewang laminasi 2D terhadap beban lateral (192S). Konferensi Nasional Teknik. Sipil 7 (KoNTeks 7). 7, S-209 - S-217. Universitas Sebelas Maret, Surakarta.

Damayanti, D. P., Agustiningtyas, R. S., \& Kuswara. (2017). Analisis jalur kritis penerapan teknologi pada konstruksi atap sirap bambu. Jurnal Permukiman, 12(2), 94107.

Fatriasari, W., \& Hermiati, E. (2008). Analisis morfologi serat dan sifat fisis-kimia pada enam jenis bambu sebagai bahan baku pulp dan kertas. Jurnal Ilmu dan Teknologi Hasil Hutan, 1(2), 67-72.

Febrianto, F., Gumilang, A., Carolina, A., \& Yoresta, F. S. (2014). Distribusi bahan pengawet larut air pada kayu diawetkan secara sel penuh dan sel kosong. Jurnal Ilmu dan Teknologi Kayu Tropis, 12 (1), 20-32.

Hakim, L., Hartono, R., \& Zalukhu, J. (2012). Asetilasi kayu rambutan (Nephelium lappaceum L), cempedak (Artocarpus integer Merr), dan rambai (Baccaurea montleyana Muell. ARG). Jurnal Teknik Industri, 1(2), 174-185.

Haris, A. (2008). Pengujian sifat fisis dan mekanis buluh bambu sebagai bahan konstruksi menggunakan ISO 22157-1:2004. (Skripsi). Departemen Hasil Hutan, Fakultas Kehutanan, Institut Pertanian Bogor.

Irawaty, W. O. (2000). Pengawetan bambu betung (Dendrocalamus asper(Schultf.) BackerexHeyne) secara Boucherie. (Skripsi). Jurusan Teknologi Hasil Hutan, Fakultas Kehutanan, Institut Pertanian Bogor.

Jasni, Damayanti, R., \& Pari, R. (2017). Ketahanan alami jenis-jenis bambu yang tumbuh di Indonesia terhadap rayap tanah. Jurnal Penelitian Hasil Hutan, 35(4), 289-301.
Krisdianto, Sudika, D. A., Wahyudi, A., \& Muslich, M. (2015). Keterawetan enam jenis kayu dari Jawa Barat dan Riau. Jurnal Penelitian Hasil Hutan, 33(4), 329-336.

Muliawan, I. W. (2014). Aplikasi teknologi bambu semen sebagai dinding di Desa Penglipuran Kabupaten Bangli. Paduraksa, 3(1), 18-31.

Muslich, M., \& Rulliaty, S. (2014). Ketahanan bambu petung (Dendrocalamus asper Backer) yang diawetkan dengan CCB terhadap serangan penggerek di laut. Jurnal Penelitian Hasil Hutan, 32(3), 199-208.

Priadi, T., \& Pratiwi, G. A. (2014). Sifat keawetan alami dan pengawetan kayu mangium, manii dan sengon secara rendaman dingin dan rendaman panas dingin. Jurnal Ilmu Teknologi Kayu Tropis, 12(2), 118-126.

Suhaendah, E., \& Siarudin, M. (2014). Pengawetan kayu tisuk (Hibiscus macrophyllus Roxb.) melalui rendaman dingin dengan bahan pengawet Boric Acid Equivalent. Jurnal Penelitian Hasil Hutan, 32(2), 103-110.

Sulastiningsih, I., \& Santoso, A. (2012). Pengaruh jenis bambu, waktu kempa dan perlakuan pendahuluan bilah bambu terhadap sifat papan bambu lamina. Jurnal Penelitian Hasil Hutan, 30(3), 198-206.

Sumaryanto, A., Hadikusumo, S. A., \& Lukmandaru, G. (2013). Pengawetan kayu gubal jati secara rendaman dingin dengan pengawet boron untuk mencegah serangan rayap kayu kering (Cryptotermes cynocephalus Light.). Jurnal Ilmu Kehutanan, 7(2), 93-107.

Susanti, E. (2001). Pengawetan bambu tali (Gigantochloa apus Kur:) dengan menggunakan metode Boucherie. (Skripsi). Institut Pertanian Bogor, Jurusan Teknologi Hasil Hutan, Fakultas Kehutanan.

Yamauchi, S., Sakai, Y., Watanabe, Y., Kubo, M. K., \& Matsue, H. (2007). Distribution boron in wood treated with aqueous and methanolic boron acid solutions. Journal of Wood Science, 53, 324-331. 
